\title{
EFFECTIVENES OF STRENGTHENING LOADED RC BEAMS WITH FRCM SYSTEM
}

\author{
Z. BLIKHARSKYY ${ }^{1}$, K. BRÓZDA ${ }^{2}$, J. SELEJDAK ${ }^{3}$
}

\begin{abstract}
The composite materials as FRP (Fiber Reinforced Polymers), which are characterized by benefits resulting from the combination of high strength reinforcement (as carbon, glass, steel or aramid fibers) with synthetic matrix are increasingly used to reinforce existing structures. Reinforcing System as FRCM (Fibre Reinforced Cementitious Matrix), which includes, among others, Ruredil X Mesh Gold System, is much less commonly used. However, the uniform and practical methods for calculating composite reinforced structures are not determined. Especially when considering the real conditions of structure exploitation, which requires further research in this field. In the paper the initial loading level influence on the efficiency of reinforced concrete beams strengthen using system Ruredil $\mathrm{X}$ Mesh Gold was investigated.
\end{abstract}

Keywords: RC beam, composite materials, FRCM, Ruredil X Mesh Gold system, strengthening

\section{INTRODUCTION}

The growing group of scientists, both domestically and abroad, exploring opportunities resulting to use the composite materials to reinforce the building structures. In comparison with traditional methods and materials used to strengthening reinforced concrete (RC) structures, such solutions are characterized by lots of significant advantages. Despite this, there is the need to seek solutions that

\footnotetext{
${ }^{1}$ Prof., PhD., Eng., Czestochowa University of Technology, The Faculty of Civil Engineering, Department of Concrete Structures and Geotechnics, e-mail: zblikharskyy@bud.pcz.czest.pl

${ }^{2}$ MSc. Eng., Czestochowa University of Technology, The Faculty of Civil Engineering, Department of Concrete Structures and Geotechnics, e-mail: kbrozda@bud.pcz.czest.pl

${ }^{3}$ Assoc. Prof., PhD., Eng., Czestochowa University of Technology, The Faculty of Civil Engineering, Department of Concrete Structures and Geotechnics, Ul. Akademicka 3, 42-200 Czestochowa, Poland, e-mail:

jselejdak@bud.pcz.czest.pl
} 
reduce the problems associated with repairing and strengthening. These benefits include, inter alia [6-9]:

- relatively low dead load;

- possible to use in order to strengthen the various construction elements (slabs, beams, columns, etc.);

- slight increase in the geometric dimensions of the structure the strengthening;

- high efficiency in the process of strengthening.

Composite materials used for strengthening structural elements combine the advantages resulting from the connection of the high-strength fiber reinforcement (carbon, glass, metal, aramid, etc.) and synthetic matrix (usually as epoxy resins), which provides the cooperation between structure and strengthening. Obtained in this way material is one of the most common materials used for strengthening: FRP - Fiber Reinforced Polymer [5].

In comparison to the group of FRP composites, the FRCM (Fibre Reinforced Cementitious Matrix) composites involves a number of advantages, which include $[4,10]$ :

- excellent adhesion to wet surfaces;

- resistance to UV rays;

- absence of toxic compounds;

- high resistance to the high temperatures.

To FRCM composite group the Ruredil X Mesh Gold system can be included. In the Fig. 1 a typical sequence of application of the system was shown [14].

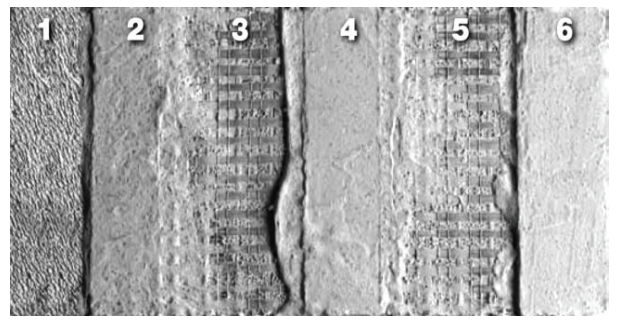

1. The concrete surface.

2. The first layer of Ruredil X Mesh M750 mortar.

3. Ruredil X Mesh Gold mesh.

4. The second layer of Ruredil X Mesh M750 mortar.

5. Ruredil X Mesh Gold mesh (if necessary).

6. The third layer of Ruredil X Mesh M750 mortar (in the case of position 5).

Fig. 1. The strengthening of Ruredil X Mesh Gold [14]

\section{THE ANALYSIS OF EXISTING RESEARCH AND STUDIES}

By analyzing the available publications, it can be noted that existing research are mainly based on systems FRP [4-10]. The FRCM strengthening, which include Ruredil X Mesh Gold system, is 
significantly less common [1-3]. Some publications raise issues related to the research of strength and deformation of beams reinforced by this FRCM system [11, 12], but not include the effect of the initial beam load. However, the uniform and practical methods for calculating the reinforced concrete strengthened by composites are not exactly specify, especially taking into consideration the actual operating conditions of structure which requires further studies and researches in this field.

\section{METHOD AND MATERIALS}

\subsection{THE PURPOSE OF RESEARCH}

The aim of the study is to analyze the influence of preload of the RC beam on the effectiveness of the strengthening of the FRCM system.

\subsection{THE METHODOLOGY OF RESEARCH}

The aim of the research was to make series of eight prototypes of reinforced concrete beams. Each of the beams had identical cross-sectional geometric dimensions and were made of the same concrete mixture and reinforcement (Fig. 2). For two beams the research was conducted without strengthening to determine their actual load capacity $\left(M_{u}^{\exp }\right)$ and their destructive character. Other beams were strengthened and investigated under the action of the three load levels i.e. 0.5, 0.7 and $0.9 M_{u}^{\exp }$ (two identical beams at each level).

Prototypes were sign in the following way: B - beam; Z - without strengthening; $\mathrm{P}$ - strengthened (Table 1). The first group of digits is a serial number and a number of beams, while the second - a load level at which the strengthening was made. For example „BP 1.5-0.7” means the fifth beam of the first series which was strengthened under level 0,7 of the load $M_{u}^{\exp }$, and then proceed short-time load of beam until reach the critical load.

Assumed dimensions of beams are: length $2100 \mathrm{~mm}$, width $100 \mathrm{~mm}$, height $200 \mathrm{~mm}$. The stirrups are made of reinforcing steel A-III- class and spaced near the support, on the remaining length is used Bp-I-class reinforcement wire [13]. Stirrups are spaced in 65 to $120 \mathrm{~mm}$. The stirrups were welding of straight bars in factory. Scheme of beams and reinforcement is shown in Fig. 2. 


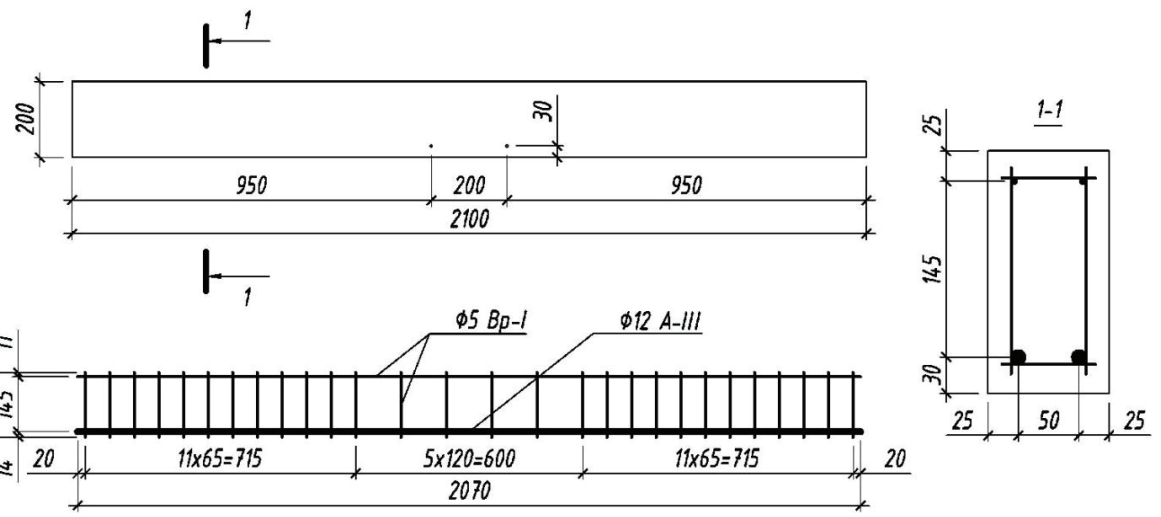

Fig. 2. The scheme of RC beam (longitudinal and transverse reinforcement)

Approximately in the middle of span of each beam, a handles for stress measurement were welded to reinforcement.

Determining the physical and mechanical properties of reinforcing steel bars was done by investigation of standard samples. The graph of tensile strength of samples attached to the test machine was generated automatically.

Concrete mixing ratios for cement, sand, aggregate is taken as 1:1.14:2.62 and water-cement ratio $\mathrm{W} / \mathrm{C}=0,35$. The Portland cement M400 (from cement plant), pure quartz sand, crushed rock (fraction: 5-10 $\mathrm{mm}-45 \%, 10-20 \mathrm{~mm}-55 \%$ ) were used.

In order to identify physical and mechanical properties of concrete tests were performed and the results are shown in Table 1. The properties correspond to the class of concrete C30/35. 
Table 1. Characteristics of the analyzed beams

\begin{tabular}{|c|c|c|c|c|c|c|c|}
\hline \multirow[b]{2}{*}{ No. } & \multirow[b]{2}{*}{$\begin{array}{c}\text { Mark of } \\
\text { beam }\end{array}$} & \multirow[b]{2}{*}{$\begin{array}{c}\text { Cross- } \\
\text { sectional } \\
\text { dimensions } \\
b \times h, \mathrm{~mm}\end{array}$} & \multicolumn{4}{|c|}{ Reinforcement } & Concrete \\
\hline & & & $\begin{array}{c}\text { Cross } \\
\text { sectional } \\
\text { area } \\
\mathrm{cm}^{2}\end{array}$ & $\begin{array}{c}\text { Characteristic } \\
\text { yield strength } \\
f_{y k}, \mathrm{MPa}\end{array}$ & $\begin{array}{c}\text { Modulus } \\
\text { of } \\
\text { elasticity } \\
E_{s}, \mathrm{MPa}\end{array}$ & $\begin{array}{c}\text { Longitudinal } \\
\text { reinforcement } \\
\text { ratio } \\
\rho_{1}, \%\end{array}$ & $\begin{array}{c}\text { Modulus } \\
\text { of } \\
\text { elasticity } \\
E_{c m}, \\
\mathrm{MPa}\end{array}$ \\
\hline 1 & BZ1.1 & $103 \times 205$ & \multirow{8}{*}{$\begin{array}{c}2 \varnothing 12 \\
\text { A-III } \\
2.26\end{array}$} & \multirow{8}{*}{400} & \multirow{8}{*}{$210 \cdot 10^{3}$} & 1.07 & \multirow{8}{*}{$33.7 \cdot 10^{3}$} \\
\hline 2 & BZ 1.2 & $102 \times 203$ & & & & 1.09 & \\
\hline 3 & BP 1.3-0.5 & $105 \times 197$ & & & & 1.09 & \\
\hline 4 & BP $1.4-0.5$ & $99 \times 208$ & & & & 1.10 & \\
\hline 5 & BP $1.5-0.7$ & $105 \times 208$ & & & & 1.03 & \\
\hline 6 & BP 1.6-0.7 & $107 \times 203$ & & & & 1.04 & \\
\hline 7 & BP $1.7-0.9$ & $98 \times 198$ & & & & 1.16 & \\
\hline 8 & BP $1.8-0.9$ & $106 \times 205$ & & & & 1.04 & \\
\hline
\end{tabular}

The strengthening of beams were made in the Ruredil X Mesh Gold system. Declared by the manufacturer characteristics of mesh [14] are presented in Table 2 and Table 3. The fibres treated as the strengthening, while the mortar is used for fixing them to the beam.

Table 2. Characteristics of the analyzed Ruredil X Mesh Gold

\begin{tabular}{|l|l|l|}
\hline No. & Property & Value \\
\hline 1 & Weight of mesh in area of $1 \mathrm{~cm}^{2}, \mathrm{~g}$ & 1.56 \\
\hline 2 & Tensile strength, MPa & 5800 \\
\hline 3 & Modulus of elasticity, MPa & $270 \cdot 10^{3}$ \\
\hline 4 & Limit deflection, \% & 2.15 \\
\hline 5 & The equivalent weight of the dry film thickness in the longitudinal direction, $\mathrm{mm}$ & 0.0445 \\
\hline 6 & The equivalent weight of the dry film thickness in the transverse direction, $\mathrm{mm}$ & 0.0115 \\
\hline 7 & Tensile strength in the longitudinal direction per unit width, $\mathrm{kN} / \mathrm{m}$ & 264 \\
\hline 8 & Tensile strength in the transverse direction per unit width, $\mathrm{kN} / \mathrm{m}$ & 66.5 \\
\hline
\end{tabular}


Table 3. Characteristics of the analyzed Ruredil X Mesh M750 mortar

\begin{tabular}{|l|l|l|}
\hline No. & Property & Value \\
\hline 1 & The quantity of water per $100 \mathrm{~kg}$ of a solution, 1 & $24-26$ \\
\hline 2 & The quantity of dried product, $\mathrm{kg} / \mathrm{m}^{2} / \mathrm{mm}$ & $1.210-1.230$ \\
\hline 3 & Compressive strength after 28 days, MPa & 29 \\
\hline 4 & Flexural strength after 28 days, MPa & 3.5 \\
\hline 5 & Modulus of elasticity, MPa & $6 \cdot 10^{3}$ \\
\hline
\end{tabular}

Determination of flexural strength of beams is done. The load level was monitored by using dynamometers K1 and K2 with spacing of $1900 \mathrm{~mm}$, which acted as support of beam at the same time. The load was applied as concentrated forces with spacing of $1 / 3$ of beam span. Deformation of reinforcement was measured by instruments Ai1 and Ai2 with an accuracy of $0.001 \mathrm{~mm}$. The deformation at the height of the concrete cross section was monitored by sensors $i 1 \div i 10$. To control deflections five sensors (deflectometers PAO1 $\div$ PAO5) were used and two sensors (P1, P2) to control settlement of the supports of test fixture. To monitor the slippage at the interface between strengthening and tension zone of the concrete the measuring clock $\mathrm{C} 1$ was installed. Location of individual measuring devices was illustrated in the diagram in Fig. 3.

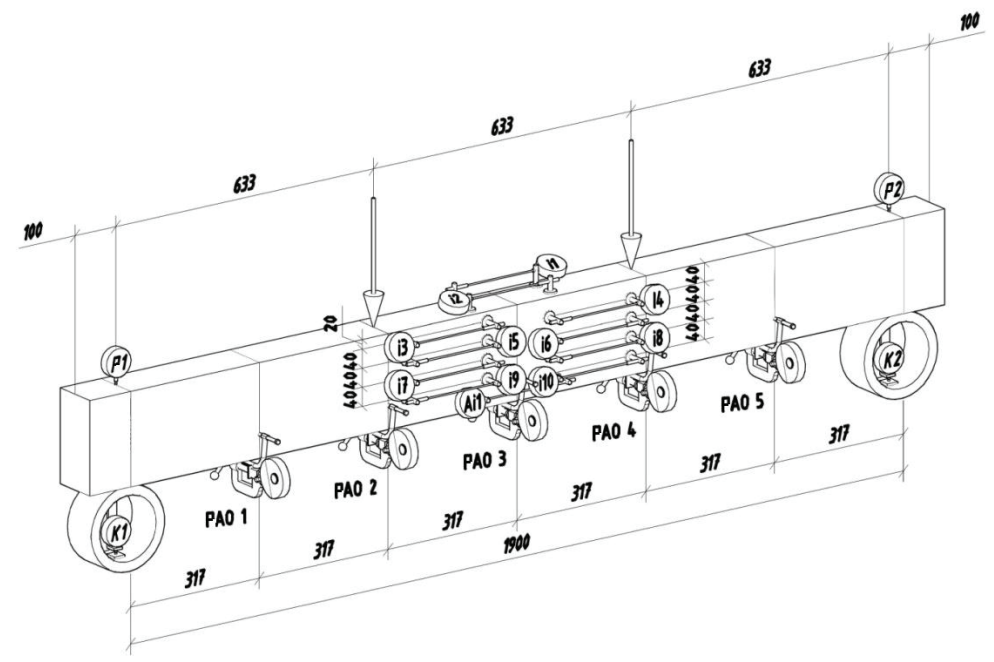

Fig. 3. Schematic location of sensors 
It was assumed that the intensity of the load was applied in stages from the level of $0.05 M_{u}^{\exp }$ to 0.3 $M_{u}^{\exp }$. Then the load has increased by the value of $0.1 M_{u}^{\exp }$ and was exposed to the action for further $15 \mathrm{~min}$. The operation was repeated until the beam failure. General scheme of the test fixture was shown in the Fig. 4.

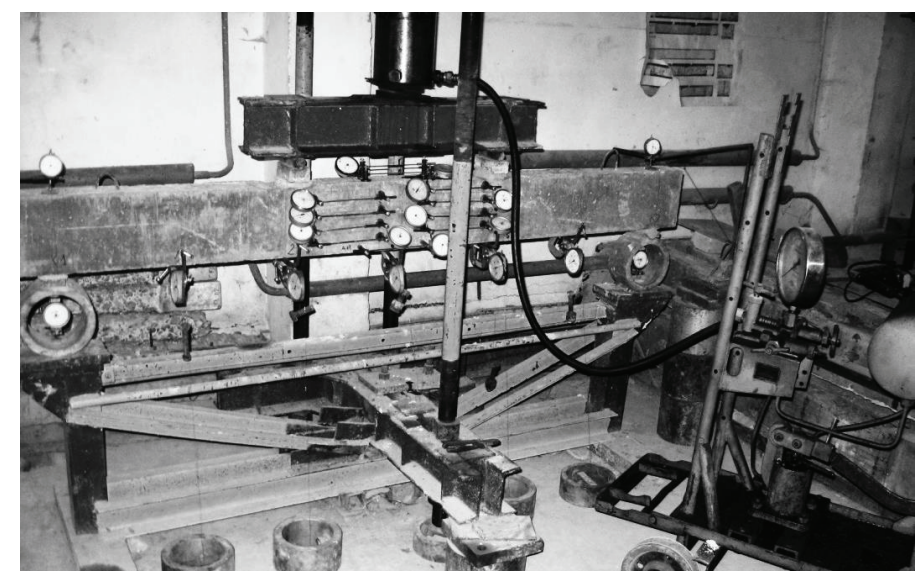

Fig. 4. Test fixture

During the test the beams marked as BP was exposed to the action of load with the appropriate intensity level $\left(0.5 ; 0.7\right.$ and $\left.0.9 M_{u}^{\exp }\right)$, and then recorded by the system. Strengthening by FRCM system was performed as shown in the Fig. 5, in the following order of technological process:

- concrete surface cleaning;

- moisten the concrete surface;

- applying the first layer of the mortar of a thickness 2-3 mm,

- sticking the one layer of the mesh of a width $10 \mathrm{~cm}$ (9 fiber bundles);

-5 min of the technological break;

- applying the second layer of the mortar of a thickness 2-3 $\mathrm{mm}$.

The research was conducted not earlier than 5 days after strengthening. Beam was loaded in stages at $0.1 M_{u}^{\exp }$ sequentially for $15 \mathrm{~min}$ until failure. 


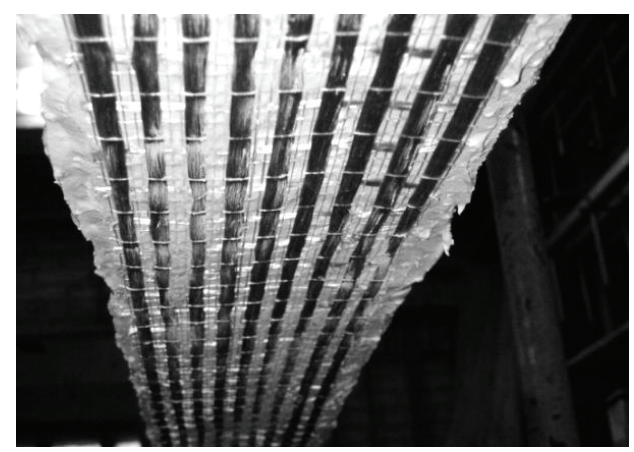

Fig. 5. Ruredil X Mesh Gold after fitting

\section{RESULTS}

The obtained results are illustrated as relation between deformation of strengthen and bending moment (Fig. 6), according to which effective load capacity of the beams were determined.

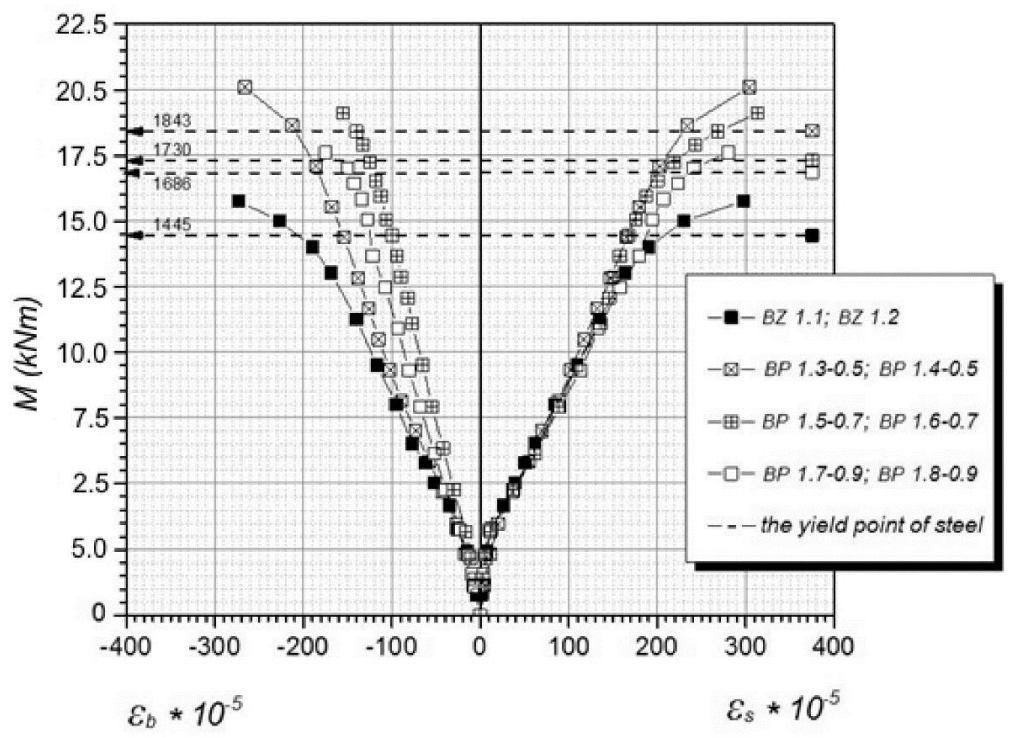

Fig. 6. Bending moment/strains curve of reinforcement and compression zone of the concrete 
Each of the tested beams were destroyed as a result of exceeding the yield strength of the reinforcement. The slippage of mesh fibers was not observed. Results are presented in the table 4 .

Table 4. Strength test results

\begin{tabular}{|c|c|c|c|c|}
\hline \multirow{2}{*}{ No. } & \multirow{2}{*}{ Mark of beam } & \multicolumn{2}{|c|}{ Load at breakage, $\mathrm{kN} \cdot \mathrm{m}$} & \multirow{2}{*}{$\begin{array}{c}\text { Load capacity } \\
\text { increase, \% }\end{array}$} \\
\hline & & $M_{u}^{\exp }$ & $\overline{M_{u}^{\exp }}$ & \\
\hline 1 & BZ1.1 & 14.56 & \multirow{2}{*}{14.45} & \multirow{2}{*}{ - } \\
\hline 2 & BZ 1.2 & 14.34 & & \\
\hline 3 & BP $1.3-0.5$ & 18.63 & \multirow{2}{*}{18.43} & \multirow{2}{*}{27.58} \\
\hline 4 & BP $1.4-0.5$ & 18.24 & & \\
\hline 5 & BP $1.5-0.7$ & 17.42 & \multirow{2}{*}{17.30} & \multirow{2}{*}{19.76} \\
\hline 6 & BP $1.6-0.7$ & 17.19 & & \\
\hline 7 & BP $1.7-0.9$ & 16.56 & \multirow{2}{*}{16.86} & \multirow{2}{*}{16.71} \\
\hline 8 & BP $1.8-0.9$ & 17.17 & & \\
\hline
\end{tabular}

For strengthened beams by The Ruredil X Mesh Gold system, loaded by $0.5 M_{u}^{\text {exp }}$ efficiency of strengthening increased by $27.58 \%$, for the load $0.7 M_{u}^{\exp }$ - by $19.76 \%$, and for the load $0.9 M_{u}^{\exp }$ - by $16.71 \%$. The results analyze shows that the effectiveness of strengthening, reaches values inversely proportional to the increase of load intensity.

\section{CONCLUSIONS}

During the analyze the effectiveness of the strengthening of the FRCM system of the preloaded RC beams was taken into consideration. The Ruredil X Mesh Gold system was chosen as a system of strengthening. The research includes the eight prototypes of RC beams: two beams without strengthening and six beams which were strengthened by FRCM system. The beams were loaded in stages until failure. The main cause of damage was exceeding the yield strength of the reinforcement. Based on the experimental investigations it was concluded that through the using the Ruredil X Mesh Gold system the strengthening increased the load capacity by $16.71 \div 27.58 \%$. Moreover, it was noticed that the reached values of increasing are inversely proportional to the value of initial load. Consequently, the lower the initial load was, the higher the load capacity was achieved by strengthening. Therefore if strengthening by this system is necessary, it is recommended to reduce the load on the structure as much as possible. 


\section{REFERENCES}

1. V. Alecci, G. Misseri, L. Rovero, G. Stipo, M. De Stefano, L. Feo and R. Luciano, "Experimental investigation on masonry arches strengthened with PBO-FRCM composite", Composites Part B: Engineering (100), pp. 228239, 2016.

2. V. Alecci, F. Focacci, L. Rovero, G. Stipo and M. De Stefano, "Extrados strengthening of brick masonry arches with PBO-FRCM composites: Experimental and analytical investigations", Composite Structures (149), pp. 184-196, 2016.

3. V. Alecci, F. Focacci, L. Rovero, G. Stipo and M. De Stefano, "Intrados strengthening of brick masonry arches with different FRCM composites: Experimental and analytical investigations", Composite Structures (176), pp. 898-909, 2017.

4. S. Babaeidarabad, G. Loreto and A. Nanni, "Flexural Strengthening of RC Beams with an Externally Bonded Fabric-Reinforced Cementitious Matrix", Journal of Composites for Construction 18(5), 2014.

5. K. Brózda and J. Selejdak, „Methods of increasing the strength properties of RC beams” (in Polish), Zeszyty Naukowe. Quality. Production. Improvement 1(4), pp. 28-39, 2016.

6. B. Fu, "Debonding failure in FRP-strengthened RC beams: prediction and suppression", The Hong Kong Polytechnic University, 2016.

7. M.E. Kamińska and R. Kotynia, „Experimental tests of RC beams reinforced with CFRP tapes” (in Polish), Zeszyt 9. Katedra Budownictwa Betonowego Wydziału Budownictwa, Architektury i Inżynierii Środowiska Politechniki Łódzkiej, Łódź, 2000.

8. J. Kubicki, „Experimental research of cracked RC beams with adhesively bonded CFRP tapes” (in Polish), Building Research Institute - Quarterly 4(124), pp. 43-59, 2002.

9. A. Remennikov, M. Goldston and M. Neaz Sheikh, "Impact performance of concrete beams externally bonded with carbon FRP sheets", Mechanics of Structures and Materials: Advancements and Challenges - Hao \& Zhang (Eds). Conference: Proceedings of the 24th Australian Conference on the Mechanics of Structures and Materials (ACMSM24), At Perth, Australia, pp.1695-1699, 2016.

10. L. H. Sneeda, S. Verreb and L. Ombres, "Flexural behavior of RC beams strengthened with steel-FRCM composite”, in Engineering Structures 127, pp. 686-699, 2016.

11. T. Trapko, D. Urbańska, M. Kamiński, „Shear strengthening of reinforced concrete beams with PBO-FRCM composites", Composites Part B: Engineering (80), pp. 63-72, 2015.

12. T. Trapko, M. Musiał, "PBO mesh mobilization via different ways of anchoring PBO-FRCM reinforcements", Composites Part B: Engineering (118), pp. 67-74, 2017.

13. Technical materials of the LitMet JSC (12.06.2016): http://www.litmet.com/en/general-purpose-wire-52.html

14. Technical materials of the Ruredil Group: http://www.ruredil.it/ENG/PDFCataloghiENG/RXMeshGOLD.pdf

\section{LIST OF FIGURES AND TABLES:}

Fig. 1. The strengthening of Ruredil X Mesh Gold

Rys. 1. System wzmocnienia Ruredil X Mesh Gold

Fig. 2. The scheme of RC beam (longitudinal and transverse reinforcement)

Rys. 2. Schemat belek oraz zbrojenia podłużnego i poprzecznego

Fig. 3. Schematic location of sensors

Rys. 3. Schemat rozmieszczenia czujników

Fig. 4. Test fixture

Rys. 4. Stanowisko badawcze

Fig. 5. Ruredil X Mesh Gold after fitting

Rys. 5. Siatka Ruredil X Mesh Gold po zamocowaniu

Fig. 6. Bending moment/strains curve of reinforcement and compression zone of the concrete

Rys. 6. Wykres odkształceń pomiędzy zbrojeniem główny a strefą ściskaną betonu

Table 1. Characteristics of the analyzed beams 
Tabela 1. Charakterystyka badanych belek

Table 2. Characteristics of the analyzed Ruredil X Mesh Gold

Tabela 2. Charakterystyka siatki Ruredil X Mesh Gold

Table 3. Characteristics of the analyzed Ruredil X Mesh M750 mortar

Tabela 3. Charakterystyka zaprawy Ruredil X Mesh M750

Table 4. Strength test results

Tabela 4. Uzyskane wytrzymałości belek

\section{EFEKTYWNOŚĆ WZMOCNIENIA FRCM WSTĘPNE OBCIĄŻONYCH BELEK ŻELBETOWYCH}

Slowa kluczowe: belki żelbetowe, materiały kompozytowe, FRCM, system Ruredil X Mesh Gold, wzmocnienie

\section{STRESZCZENIE:}

Materiały kompozytowe FRP (Fiber Reinforced Polymers), które łączą w sobie korzyści wynikające z połączenia wysokiej wytrzymałości zbrojenia (włókien węglowych, szklanych, stalowych czy aramidowych) z syntetyczną matrycą są coraz powszechniej stosowane do wzmocnień konstrukcji. System wzmacniania FRCM (Fibre Reinforced Cementitious Matrix), do których należy m.in. system Ruredil X Mesh Gold, jest znacznie mniej powszechny. Do tej pory nie określono jednolitych i praktycznych metod obliczania konstrukcji wzmocnionych kompozytami, szczególnie przy uwzględnieniu rzeczywistych warunków eksploatacji konstrukcji, co wymaga przeprowadzenia dalszych badań w tym kierunku. Niniejszy artykuł poświęcono badaniom wpływu obciążenia początkowego o różnej intensywności na efektywność wzmocnienia żelbetowych belek przy użyciu systemu Ruredil X Mesh Gold. 